\title{
PENGARUH FASAD MASJID RAYA TERHADAP ARSITEKTUR MASJID-MASJID KECIL DI MAKASSAR
}

\author{
Wahyuni Jaharuddin ${ }^{1}$, Ria Wikantari $\mathbf{R}^{2}$, Afifah Harisah ${ }^{3}$ \\ 1,2,3Teknik Arsitektur, Universitas Hasanuddin Makassar \\ e-mail: *1 ywah34@yahoo.com, ${ }^{2}$ rwikantaria@gmail.com, ${ }^{3}$ ifahhussein@yahoo.co.id
}

\begin{abstract}
Abstrak_ Masjid kecil di Makassar memiliki keanekaragaman arsitektur pada fasadnya. Akan tetapi munculnya masjid-masjid kecil yang sangat mirip dengan arsitektur fasad Masjid Raya Makassar menimbulkan pertanyaan permasalahan adanya keterpengaruhan masjid kecil oleh Masjid Raya. Penelitian bertujuan untuk mendeskripsikan fasad Masjid Raya dan masjid kecil di Makassar, mengidentifikasi elemen-elemen fasad masjid kecil yang dipengaruhi oleh fasad Masjid Raya dan menjelaskan faktor-faktor yang mempengaruhi. Penelitian ini menggunakan metode deskriptif dengan analisis data kualitatif dan kuantitatif. Sampel penelitian terdiri atas Masjid Raya dan 4 (empat) masjid kecil di Makassar yaitu, Masjid Jendral Sudirman, Masjid Pondok Pesantren Nahdatul Qurra'a Walhuffadz, Masjid Shihatul Iman dan Masjid Lantja Abduh Massi yang dipilih secara teknik purposive sampling. Hasil penelitian menunjukkan bahwa Masjid kecil yang ada di Makassar yang dianggap mirip dengan Masjid Raya Makassar dipengaruhi oleh Masjid tersebut, berdasarkan Elemen fasad menurut Utami, dkk (2013), Perlengkapan visual bentuk menurut Ching (1996) dan Utami, dkk (2014). Keterpengaruhan masjid kecil dipengaruhi oleh hasil desain Arsiteknya, keinginan pengurus, dan masukan dari bebrapa jamaah. Kemiripan Masjid-masjid yang diteliti terletak pada bentuk lengkungan pada gerbang-gerbang Masjid, penggunaan kolomkolom besar, atap plat, bentuk yang simetris dan mudah dibentuk sesuai dengan ukuran lahan, bentuk kubah yang berasal dari satu pabrik, ornamen dan irama yang mirip dengan Masjid Raya Makassar.
\end{abstract}

Kata Kunci: Pengaruh Fasad; Masjid Raya; Masjid Kecil di Makassar

\begin{abstract}
Small mosques in Makassar have a variety of architectures on the facade. However, the appearance of small mosques that are very similar to Makassar Raya Mosque's facade, it occurs the question of the existence of the small mosque influenced by Raya mosque. This study aimed to describe the facade of Raya Mosque, and the small mosques in Makassar, to identify the facade elements of the small mosques that influenced by Raya Mosque's facade and to explain the influencing factors. The research used a descriptive method with a qualitative and quantitative data. The research sample consisted of Raya Mosque and 4 small mosques in Makassar were Jendral Sudirman Mosque, Pondok Pesantren Nahdatul Qurra'a Walhuffad Mosque, Shihatul Iman Mosque and Lantja Abduh Massi Mosque which selected by purposive sampling technique. The results showed that the small mosques in Makassar which considered similar to Makassar Raya Mosque indeed influenced by that mosque, based on facade elements according to Utami et al (2013), Visual equipment form according to Ching and Utami et al (2014). The influence of small mosques influenced by the architect's design results, the wishes of the board, and input from some worshipers.The similarities of the façade are in the form of arches at the gates of the mosque, the use of large columns, roof plates, symmetrical shapes and easily formed according to the size of the land, the shape of the dome which indeed came from one factory, similar ornaments and rhythms with Makassar Raya Mosque.
\end{abstract}

Keywords: Influence Façade; Grand Mosque; Small Mosque Makassar

\footnotetext{
${ }^{1}$ Teknik Arsitektur Universitas Hasanuddin Makassar

${ }^{2}$ Teknik Arsitektur Universitas Hasanuddin Makassar

${ }^{3}$ Teknik Arsitektur Universitas Hasanuddin Makassar
} 


\section{PENDAHULUAN}

Pada saat ini telah banyak ditemukannya konsep-konsep dalam dunia arsitektur. Berbagai macam konsep dilahirkan dari waktuke waktu untuk mewujudkan desain yang lebih inovatif. Salah satunya adalah konsep arsitektur Islam. Menurut Utami (2004) bahwa, Arsitektur Islam adalah gagasan dan karya arsitektur yang sesuai dengan pandangan dan kaidah-kaidah Islam tentang arsitektur dan tidak terbatas pada masjid saja.

Menurut (Fanani 2009), Arsitektur masjid dapat ditelusuri keadaan suatu masyarakat muslim, situasi kemasyarakatannya, pemahaman keagamaannya, disaat dan tempat dimana karya arsitektur masjid tersebut berada. Arsitektur masjid sebagai benda bentukan dengan sendirinya akan bisa menuntun pada penjelasan tentang pola prilaku, kehendak,keinginan, dan gagasan keagamaan masyarakat muslim disekeliling masjid tersebut.

Objek penelitian yang diambil adalah Masjid Raya Makassar, selain sebagai salah satu masjid terindah di kawasan Indonesia Timur, Masjid Raya Makassar juga merupakan saksi bisu sejarah bagi masyarakat Makassar yang pada masa penjajahan.

Masjid kecil di Makassar memiliki keanekaragaman Arsitektur pada fasadnya. Akan tetapi munculnya masjid-masjid kecil yang sangat mirip dengan Arsitektur fasad Masjid Raya Makassar menimbulkan pertanyaan permasalahan adanya keterpengaruhan masjid kecil oleh Masjid Raya. Ada beberapa Masjid di Makassar yang juga hampir menyerupai masjid raya Makassar akan tetapi warna dan penggunaan material tidak begitu mirip.

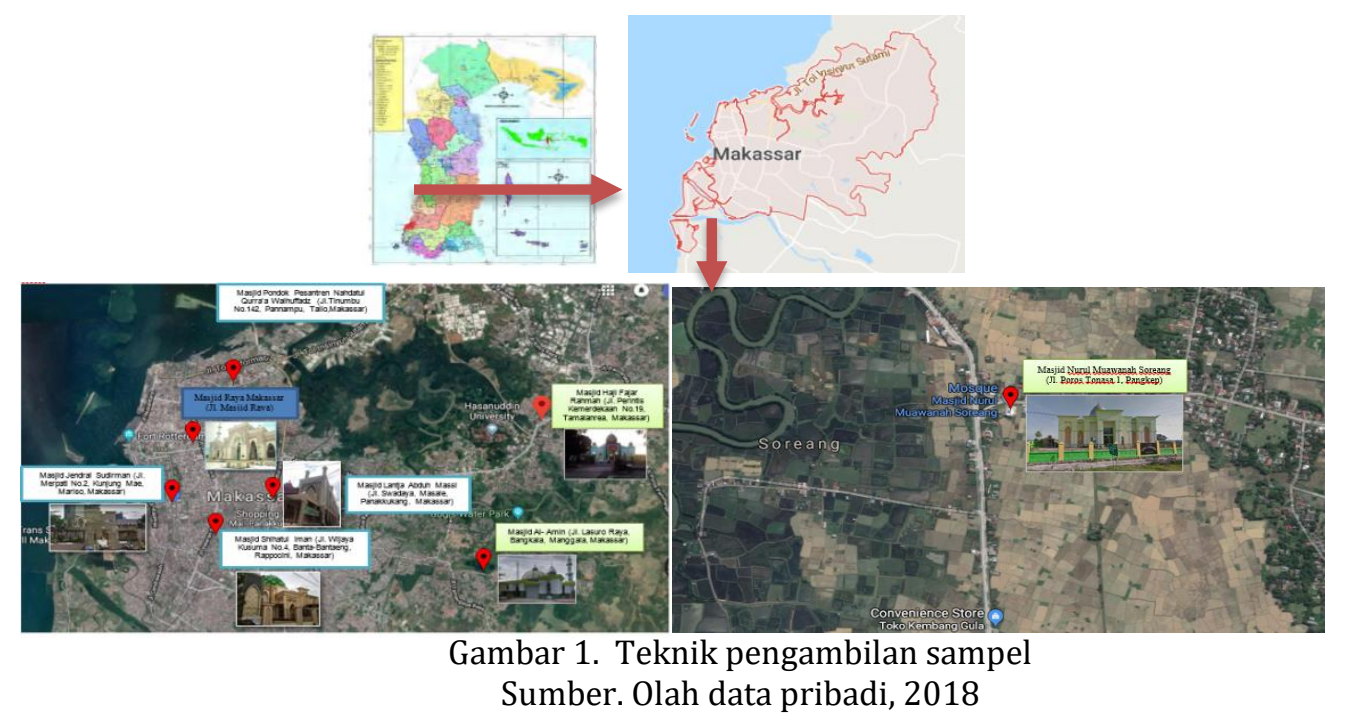

Masjid kecil yang sangat mirip dengan Masjid Raya Makassar ada 4 (empat) mesjid yaitu, (a) Masjid Lantja Abdul Massi, (b) Masjid pondok pesantren Nahdatul Qurra'a Walhuffadz, (c) Masjid Jendral Sudirman, dan (d) Masjid Shihatul Iman. Tujuan dari penelitian ini yaitu, mendeskripsikan kemiripan elemen-elemen fasad masjid kecil yang dipengaruhi oleh fasad Masjid Raya dan menjelaskan faktor-faktor yang mempengaruhi. 


\begin{tabular}{r|r} 
Pengaruh Fasad Masjid Raya & Wahyuni Jaharuddin *, \\
terhadap Arsitektur Masjid-Masjid Kecil di Makassar & Ria Wikantari R, Afifah Harisah
\end{tabular}

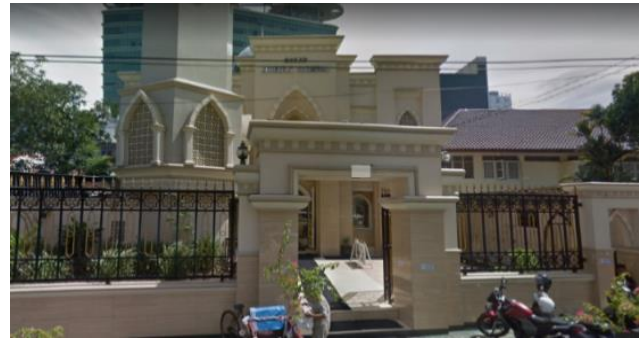

a) Masjid Jendral Sudirman (Jl. Merpati No.2, Kunjung Mae, Mariso, Makassar)

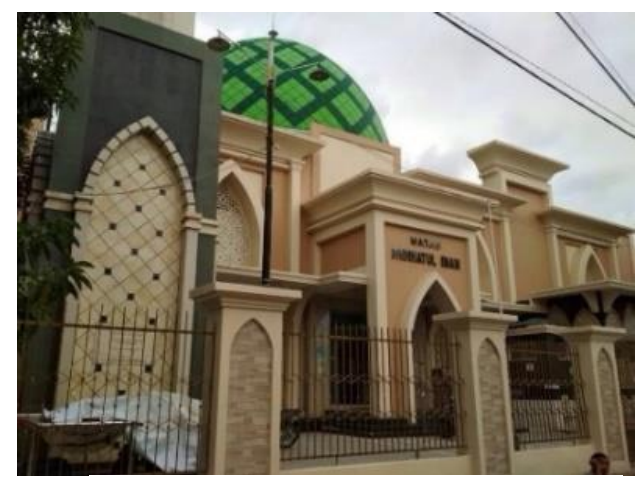

c) Masjid Shihatul Iman (Jl. Wijaya Kusuma No.4, Banta-Bantaeng, Rappocini, Makassar)

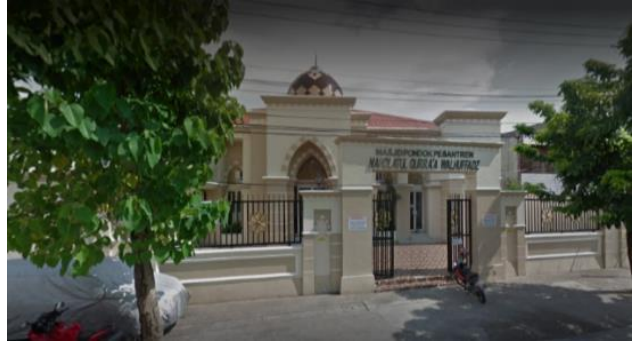

b) Masjid Pondok Pesantren Nahdatul Qurra'a Walhuffadz (Jl.Tinumbu No.142, Pannampu, Tallo,Makassar)

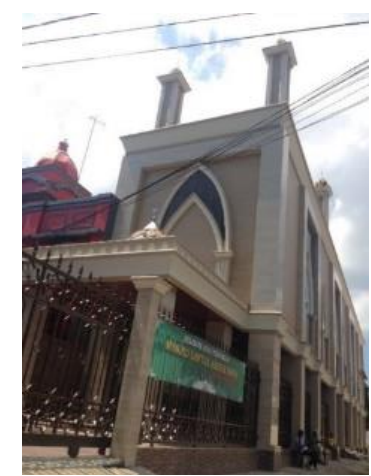

d) Masjid Lantja Abduh Massi (Jl. Swadaya, Masale, Panakkukang, Makassar)

Gambar 2. Sample masjid penelitian

Sumber. Data pribadi 2018

\section{METODE}

Penelitian ini dilakukan di wilayah Makassar yaitu, di Masjid Raya dan 4 (empat) Masjid kecil lainnya yang ada di Makassar. Dalam melakukan penelitian tentang Arsitektur Masjid Raya Makassar, penulis menggunakan metode deskriptif. Populasi adalah seluruh Masjid kecil yang ada di Makassar. Sampel sebanyak 4 (empat) Masjid kecil yang dipilih berdasarkan kemiripan fasad pada bangunannya sesuai dengan hasil survey yang telah dilakukan pada setiap Masjid kecil yang ada di Makassar. Mendeskripsikan elemen-elemen fasad Masjid kecil yang dipengeruhi oleh Masjid Raya digunakan analisis deskriptif komparatif yaitu mebandingkan fasad Masjid Raya dengan fasad Masjid kecil yang dipengaruhi dan analisis deskriptif visual yaitu data - data pemaparan. Analisis data Kuantitatif digunakan untuk menjelaskan faktor-faktor yang mempengaruhi. Digunakan analisis interpresif berdasarkan dialog antara data empiris - visual dengan teori dan keterangan narasumber dengan grafik frekuensi. 


\begin{tabular}{r|r} 
Pengaruh Fasad Masjid Raya & Wahyuni Jaharuddin *, \\
terhadap Arsitektur Masjid-Masjid Kecil di Makassar & Ria Wikantari R, Afifah Harisah \\
\hline
\end{tabular}

\section{HASIL DAN PEMBAHASAN}

\section{A. Deskripsi sampel penelitian}

1. Masjid Raya Makassar, Jalan Masjid Raya Makassar
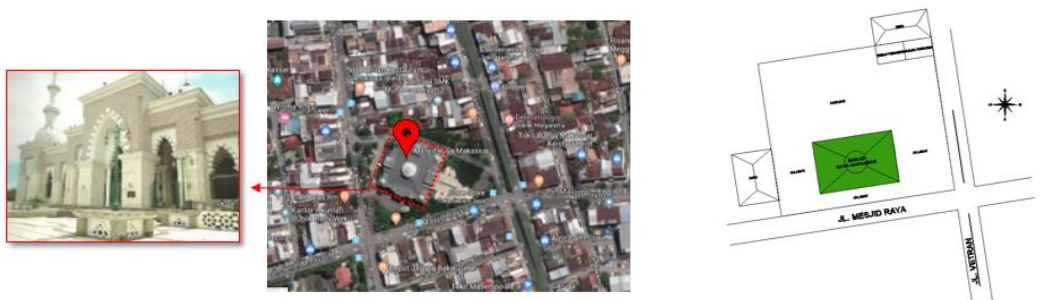

Gambar 3. Lokasi Masjid Raya Makasar Sumber. Olah data, 2018

Masjid Raya Makassar berdiri pada tahun 1949, perombakan dimulai sejak tahun 1998 dan selesai pada bulan September 1999. Arsitek Masjid Raya Makassar ialah Ir. Danny Pomanto, Ir. Furqan Affandi, dan Ir Fajar. Bangunan masjid ini terinspirasi dari Arsitektur Timur Tengah dan Spanyol. Berdasarkan hasil wawancara dengan pengurus masjid Raya yaitu Bapak Muhammad Syahril mengatakan bahwa, "Yang paling berperan penting dalam menentukan bentuk pembangunan Masjid Raya Makassar ialah para Arsitek dan Pengurus Masjid.

- Tonjolan dinding pada setiap sudut Masjid Raya Mkassar

- Irama fasad masjid 1213121

- Warna 2 mochrome

- Bertektur halus dengan bahan cor beton dan keramik bermotof pada bagian atas
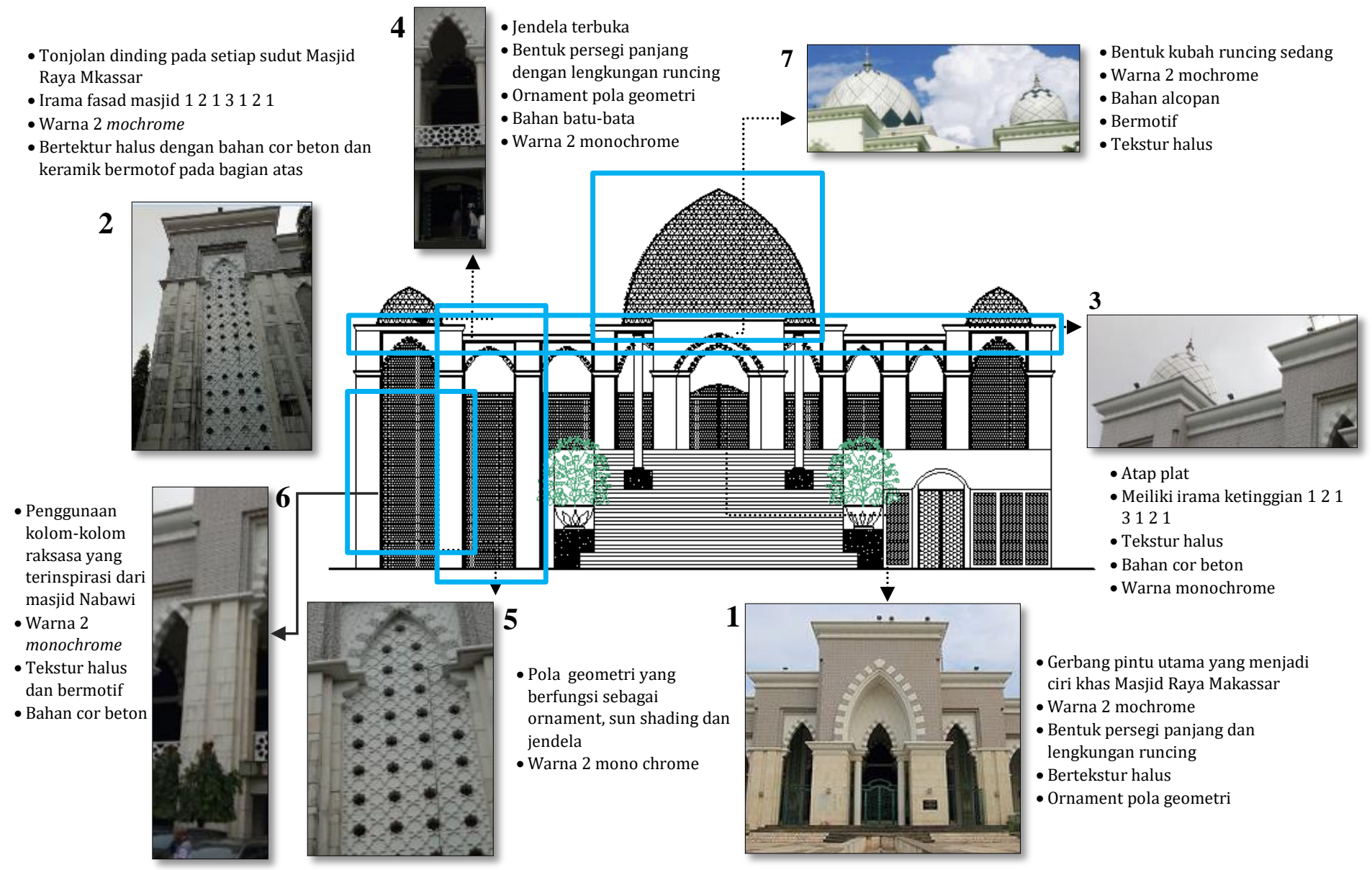

- Bentuk kubah runcing sedang - Warna 2 mochrome

- Bahan alcopan

- Bermotif

- Tekstur halus

Gambar. 4 Fasad Masjid Raya Makasar

Sumber. Digambar berdasarkan sampel kondisi lapangan, 2018 


\begin{tabular}{r|r} 
Pengaruh Fasad Masjid Raya & Wahyuni Jaharuddin *, \\
terhadap Arsitektur Masjid-Masjid Kecil di Makassar & Ria Wikantari R, Afifah Harisah \\
\hline
\end{tabular}

2. Masjid Jendral Sudirman

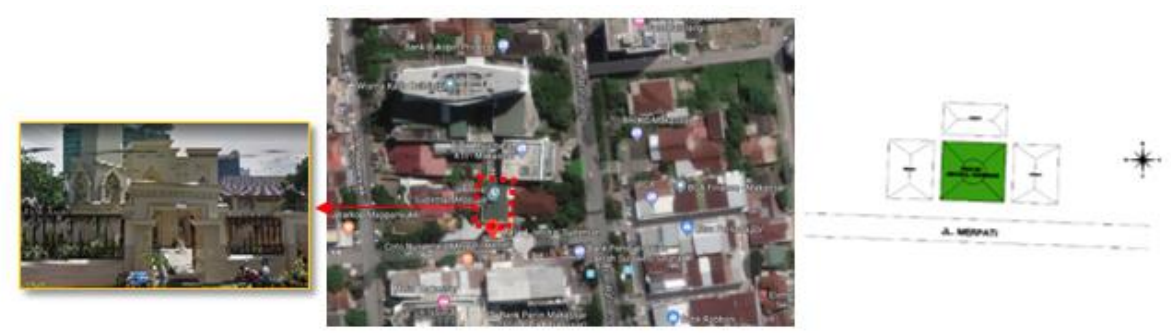

Gambar. 5 Lokasi Masjid Jendral Sudirman Sumber. Olah data, 2018

Masjid ini didirikan pada tahun 1956 dan dimulai perombakan sejak tahun 2011. Arsiteknya masjid ini adalah Bapak Ir. H. Nasrullah. Berdasarkan hasil wawancara dengan pengurus masjid bahwa, "Masjid ini terinspirasi dari masjid kubah mas di depok. Yang paling berperan penting dalam menentukan Arsitektur bangunan ini yaitu ketua dan donator Bapak alm. H. Jamaluddin".

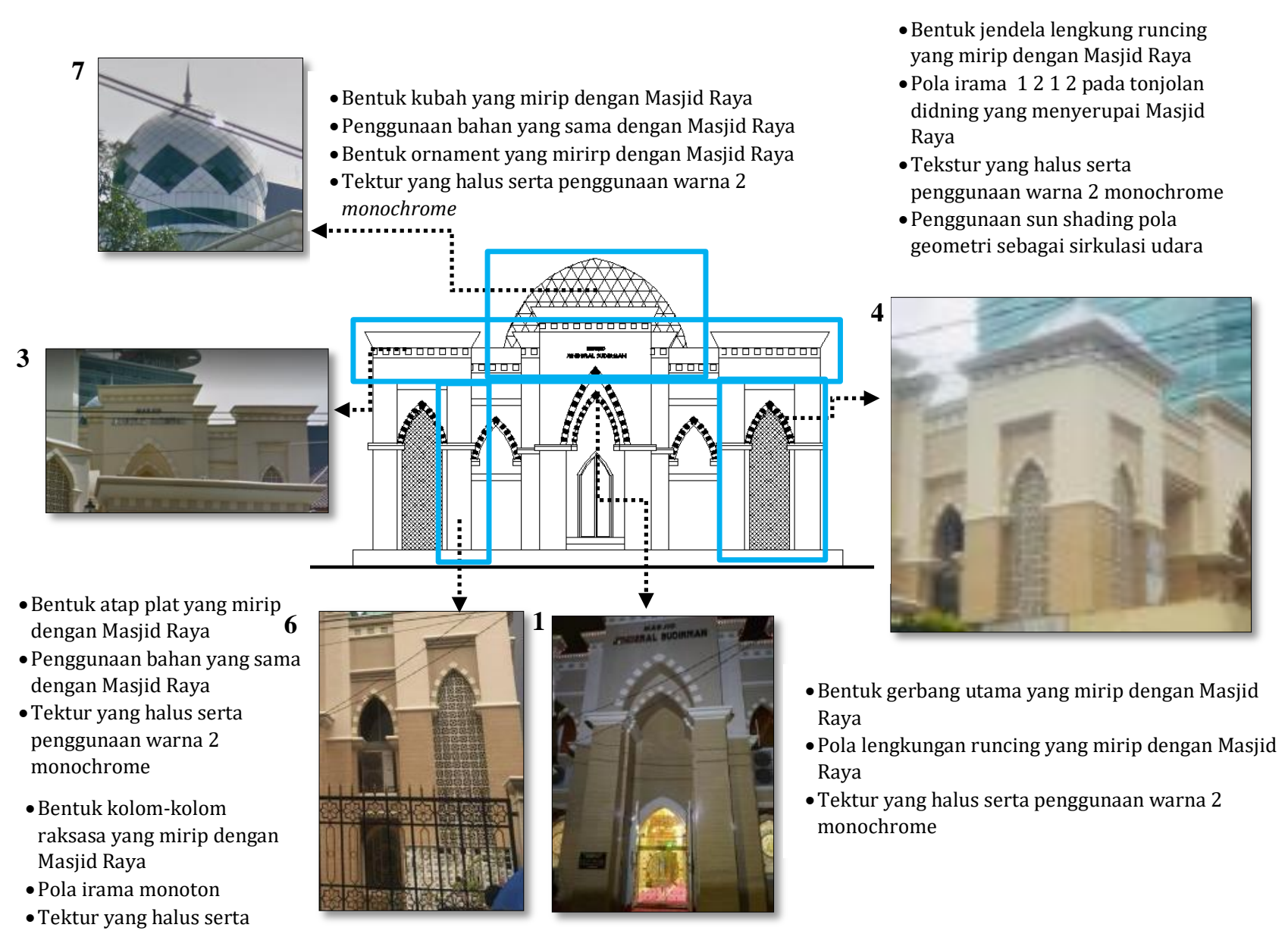

penggunaan warna 2

monochrome

-Penggunaan bahan beton

Gambar. 6 Masjid Jendral Sudirman

Sumber. Olah data, 2018 


\begin{tabular}{r|r} 
Pengaruh Fasad Masjid Raya & Wahyuni Jaharuddin *, \\
terhadap Arsitektur Masjid-Masjid Kecil di Makassar & Ria Wikantari R, Afifah Harisah \\
\hline
\end{tabular}

\section{Masjid Pondok Pesantren Nahdatul Qurra'a Walhuffadz}

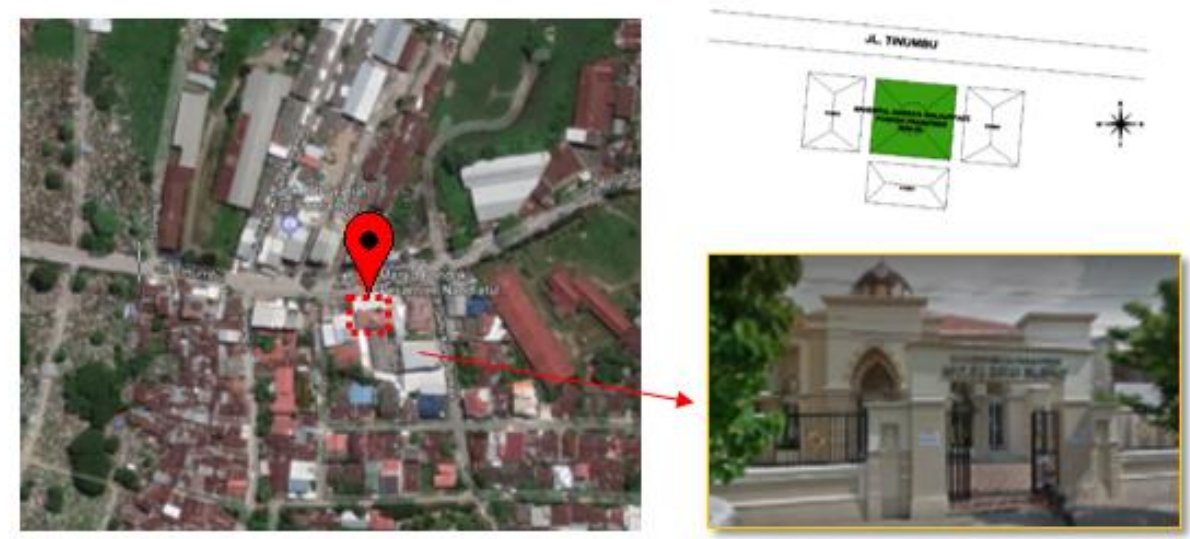

Gambar. 7 Lokasi Masjid Pondok Pesantren Nahdatul Qurra'a Walhuffadz Sumber. Olahan data, 2018

Masjid ini berdiri pada tahun 1985 dan mulai perombakan mulai bulan November 2014 sampai dengan bulan Mei 2015. Yang berperan penting dalam penentuan arsitetur bangunan masjid ini yaitu H. Syarifuddin Usman sebagai ketua pengurus Masjid dan Arsiteknya yaitu Ir. H. Nasrullah yang juga berperan sebagai pimpinan proyek dalam pembangunan masjid tersebut. Berdasarkan hasil wawancara dengan pengurus Masjid ini mengatakan bahwa, "Masjid Raya Makassar memiliki kemiripan dengan masjid ini".

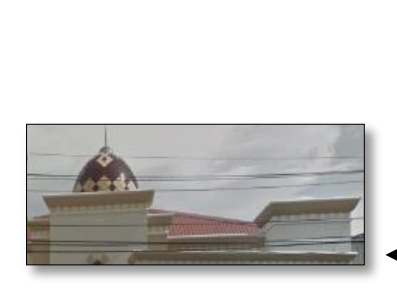

- Bentuk atap plat yang mirip dengan Masjid Raya

- Penggunaan bahan yang sama dengan Masjid Raya

- Tektur yang halus serta penggunaan warna 2 monochrome
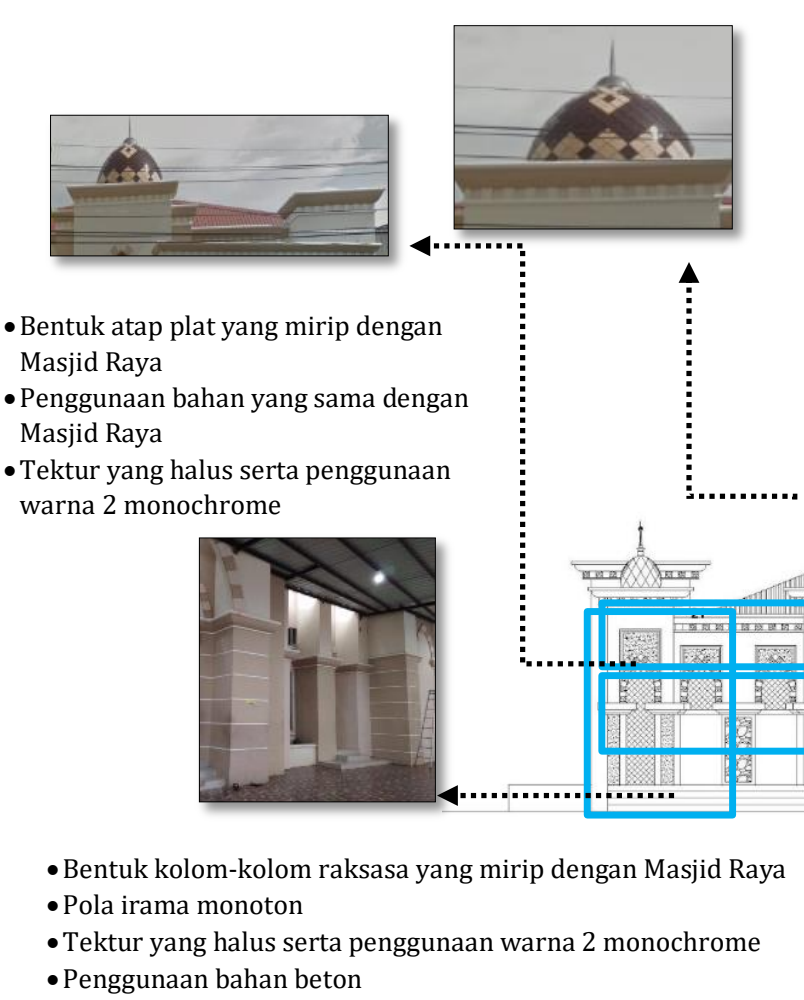
-Bentuk kubah yang mirip dengan Masjid Raya
- Penggunaan bahan yang sama dengan Masjid Raya
- Ornament yang mirirp dengan Masjid Raya
- Tektur yang halus serta penggunaan warna 2 monochrome

- Bentuk jendela lengkung runcing yang mirip dengan Masjid Raya

- Pola irama monoton

- Tektur yang halus serta penggunaan warna 2 monochrome

- Penggunaan bahan kaca

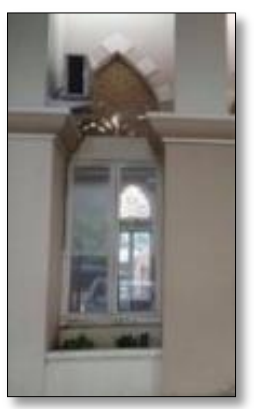

- Bentuk gerbang utama yang mirip dengan Masjid Raya

- Pola lengkungan runcing yang mirip dengan Masjid Raya - Tektur yang halus serta penggunaan warna 2 monochrome

Gambar. 8 Masjid Pondok Pesantren Nahdatul Qurra'a Walhuffadz Sumber. Olah data, 11 Maret 2018 


\begin{tabular}{r|r} 
Pengaruh Fasad Masjid Raya & Wahyuni Jaharuddin *, \\
terhadap Arsitektur Masjid-Masjid Kecil di Makassar & Ria Wikantari R, Afifah Harisah \\
\hline
\end{tabular}

4. Masjid Shihatul Iman
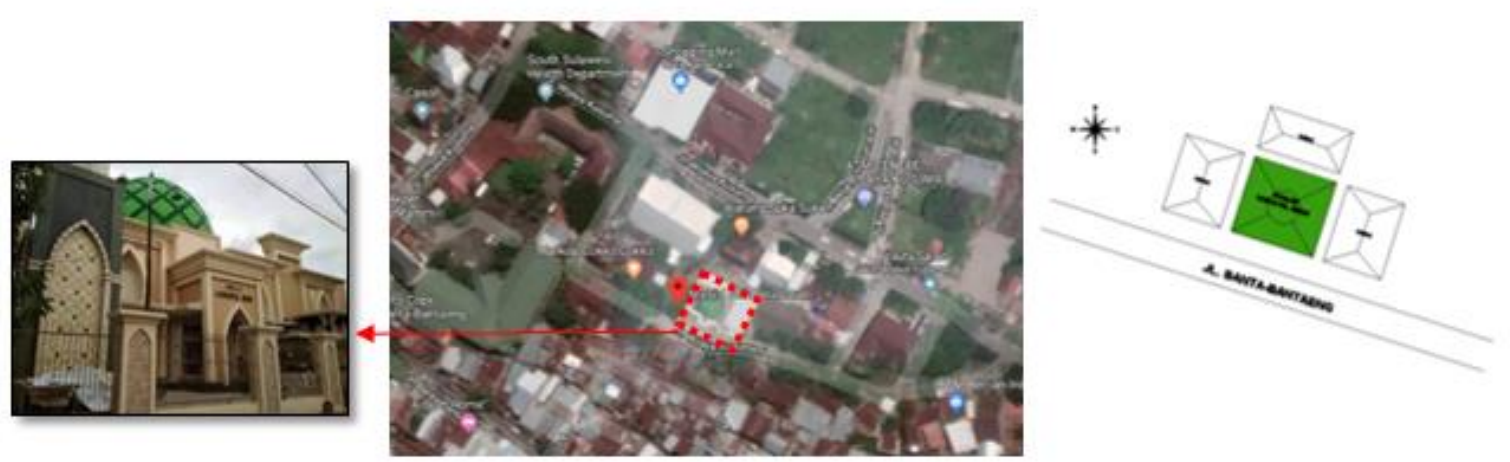

Gambar. 9 Lokasi Masjid Shihatul Iman Sumber. Olahan data, 2018

Masjid Shihatul Iman selesai pada 5 juni 2009 dan diresmikan oleh Ir. H. Ilham Arief Sirajuddin, MM. yang paling berperan penting dalam menentukan arsitektur masjid ini yaitu ketua pengurus dan arsiteknya yaitu Bapak Ir. Djoandi. Menurut wawancara dengan pengurus masjid mengatakan bahwa masjid ini mirip dengan Masjid Raya Makassar akan tetapi dalam pembangunannya tidak ada kesengajaan.

-Wujud bentuk gerbang utama yang mirip dengan Masjid Raya

- Pola lengkungan runcing yang mirip dengan Masjid Raya

- Tektur yang halus serta penggunaan warna 2 monochrome

1

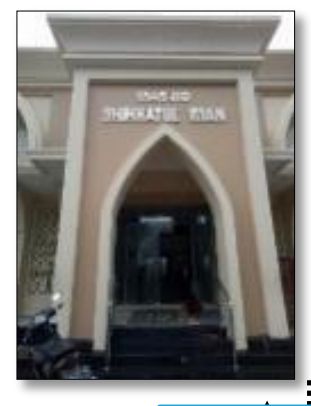

7

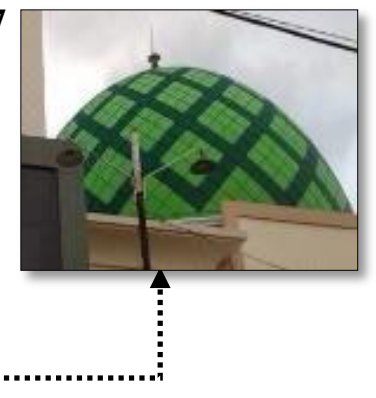

- Bentuk kubah yang mirip dengan Masjid Raya

- Penggunaan bahan yang sama dengan Masjid Raya

- Bentuk ornament yang mirirp dengan Masjid Raya

- Tektur yang halus serta penggunaan warna 2 monochrome

3
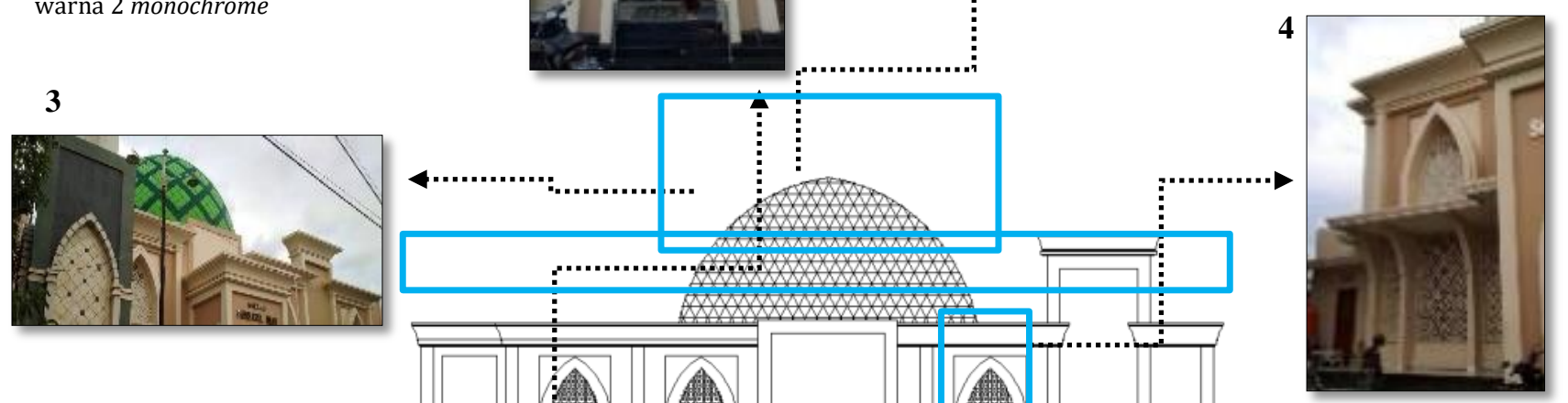

- Bentuk jendela lengkung runcing yang mirip dengan Masjid Raya

- Pola irama 1212 pada tonjolan didning yang menyerupai Masjid Raya

- Tektur yang halus serta penggunaan warna 2 monochrome

- Penggunaan sun shading pola geometri sebagai sirkulasi udara 


\begin{tabular}{r|r} 
Pengaruh Fasad Masjid Raya & Wahyuni Jaharuddin *, \\
terhadap Arsitektur Masjid-Masjid Kecil di Makassar & Ria Wikantari R, Afifah Harisah \\
\hline
\end{tabular}

5. Masjid Lantja Abduh Massi
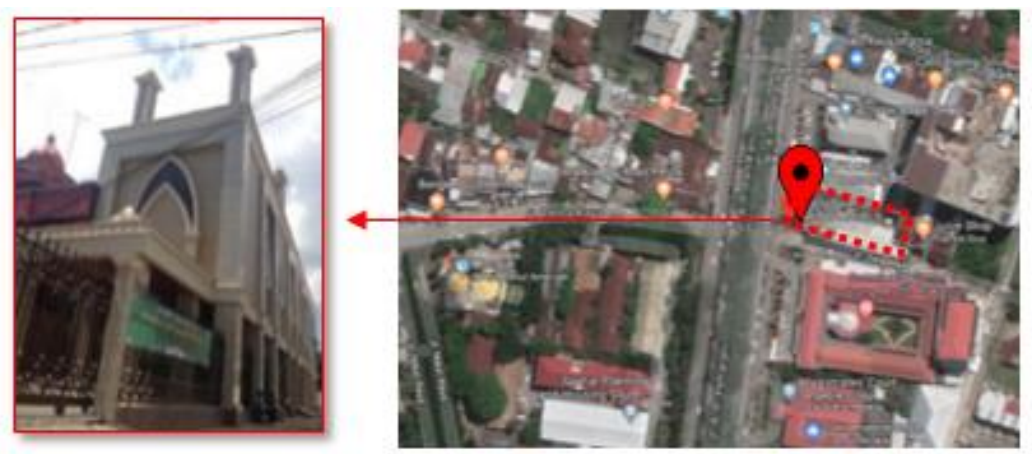

Gambar. 11 Lokasi Masjid Lantja Abduh Massı

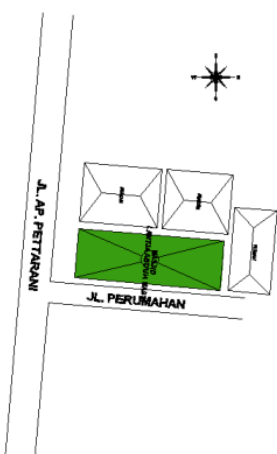

Sumber. Olahan data Adaptasi dengan google earth 2018

Masjid ini didirikan pada tahun 2015 dan selesai tanggal 1 April 2017. Arsitek Masjid ini ialah Bapak Ir. H. Ramdhan Phomanto. Penentuan Arsitektur Masjid ini berdasarkan usulan dari pemilik masjid yaitu H. Syarif dan sekaligus sebagai ketua pengurus masjid". Berdasarkan hasil wawancara dengan pengurus Masjid mengatakan bahwa, "Arsitektur masjid ini terinspirasi dari Timur Tengah.

-Wujud bentuk gerbang utama yang mirip dengan Masjid Raya

- Pola lengkungan runcing yang mirip dengan Masjid Raya

- Tektur yang halus serta penggunaan warna 2 monochrome

7

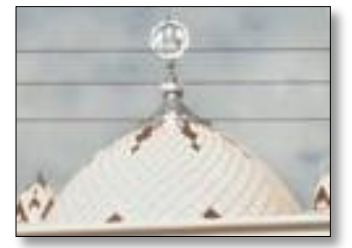

Bentuk atap plat yang mirip dengan Masjid Raya

- Penggunaan bahan yang sama dengan Masjid Raya

- Tektur yang halus serta penggunaan warna 2 monochrome
1
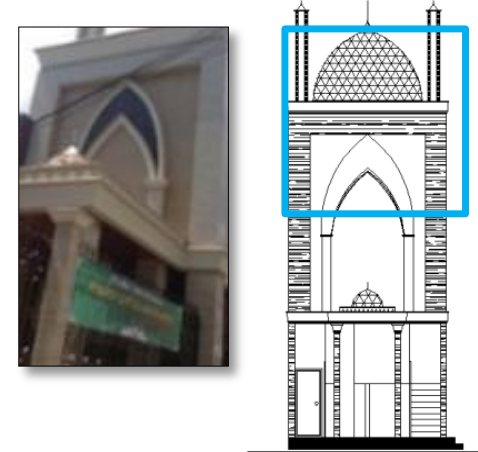

6

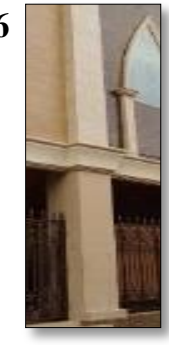

-Wujud bentuk gerbang utama yang mirip dengan Masjid Raya

- Pola lengkungan runcing yang mirip dengan Masjid Raya

- Tektur yang halus serta penggunaan warna 2 monochrome

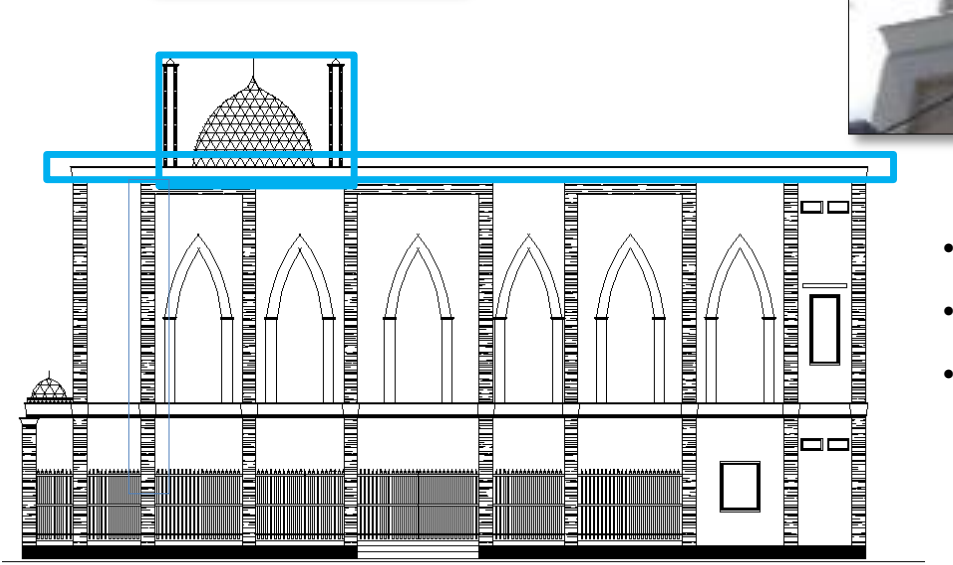

- Bentuk atap plat yang mirip dengan Masjid Raya - Penggunaan bahan yang sama dengan Masjid Raya - Tektur yang halus serta penggunaan warna 2 monochrome 


\begin{tabular}{r|r} 
Pengaruh Fasad Masjid Raya & Wahyuni Jaharuddin *, \\
\cline { 2 - 2 } terhadap Arsitektur Masjid-Masjid Kecil di Makassar & Ria Wikantari R, Afifah Harisah
\end{tabular}

\section{B. Hasil Responden dari Keempat Masjid Penelitian}

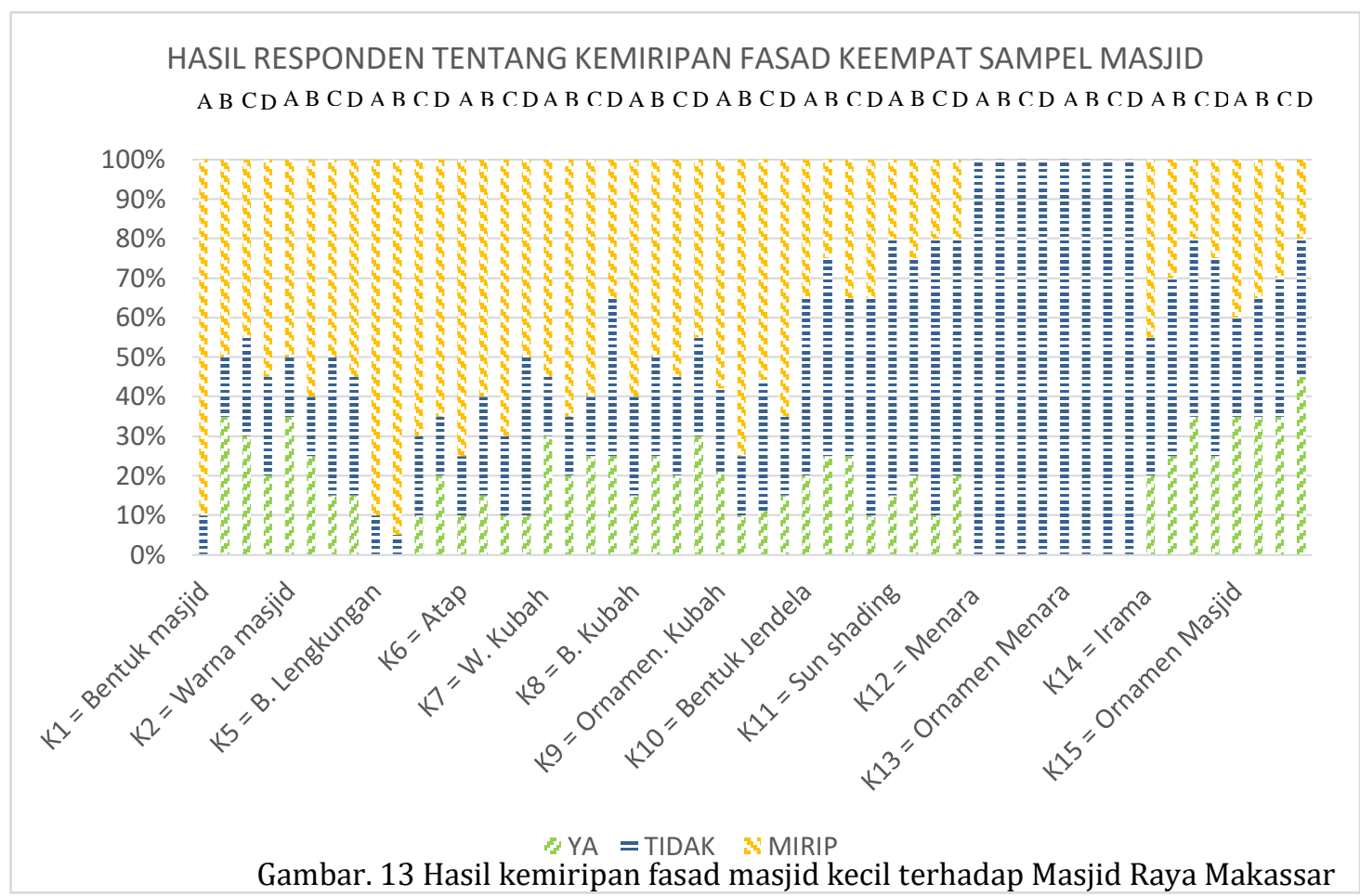

A = Masjid Jendral Sudirman $\mathrm{B}=$ Masjid Pondok Pesantren Nahdatul Qurra'a Walhuffadz C = Masjid Shihatul Iman D = Masjid Lantja Abduh Massi

Berdasarkan persepsi responden dari tiap-tiap sample masjid, rata-rata mengatakan bahwa kemiripan masjid tersebut terletak pada lengkungan, warna, kolom-kolom raksasa yang menonjol, serta gerbang-gerbang masjidnya. Adapun berdasarkan hasil responden bahwa masjid yang paling mirip dengan Masjid Raya Makassar yaitu, Masjid Jendral Sudirman dan Masjid Pondok Pesantren Nahdatul Qurra'a Walhuffadz. Hal ini disebabkan karena Masjid Raya merupakan Masjid Modern dan tidak ketinggalan jaman, penggunaan material yang mudah didapatkan, dan bentuk yang mudah diterapkan dilahan mana saja.

\section{Elemen Fasad dari keempat Masjid penelitian}

Tabel 1. Rangkuman elemen fasad dari keempat Masjid penelitian

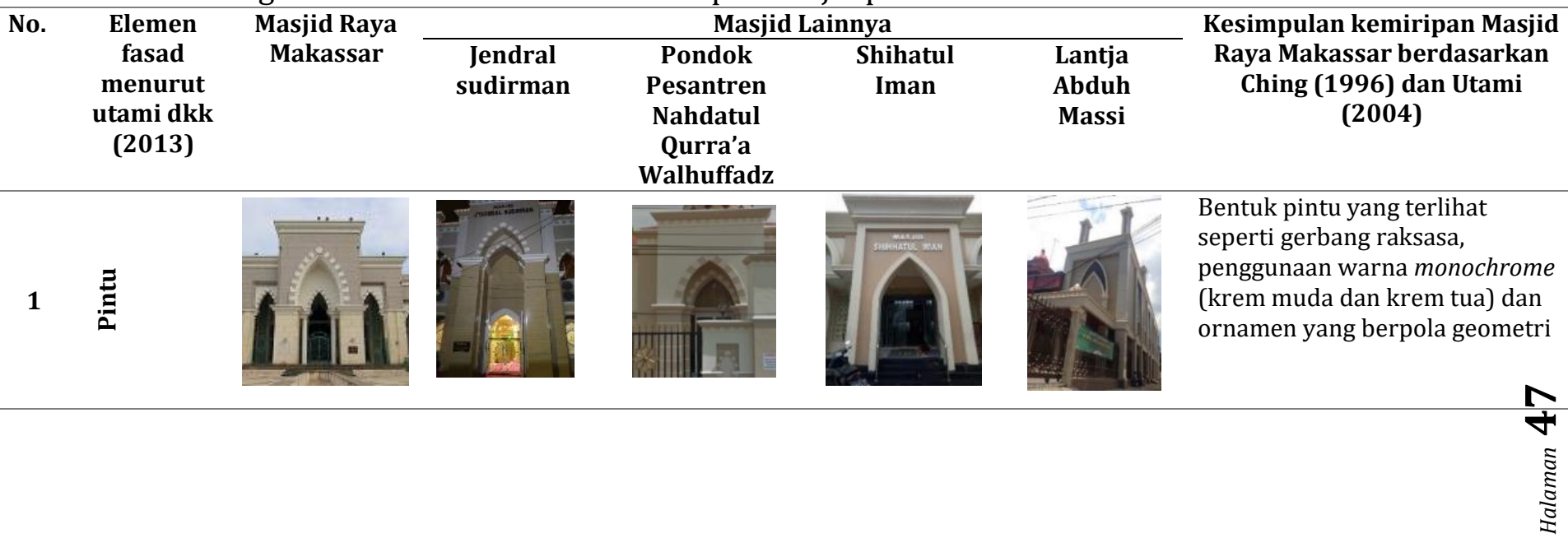




\begin{tabular}{r|r} 
Pengaruh Fasad Masjid Raya & Wahyuni Jaharuddin *, \\
\cline { 2 - 2 } terhadap Arsitektur Masjid-Masjid Kecil di Makassar & Ria Wikantari R, Afifah Harisah
\end{tabular}

\begin{tabular}{|c|c|c|c|c|c|c|c|}
\hline \multirow{2}{*}{ No. } & \multirow[b]{2}{*}{$\begin{array}{c}\text { Elemen } \\
\text { fasad } \\
\text { menurut } \\
\text { utami dkk } \\
(2013)\end{array}$} & \multirow{2}{*}{$\begin{array}{l}\text { Masjid Raya } \\
\text { Makassar }\end{array}$} & \multicolumn{4}{|c|}{ Masjid Lainnya } & \multirow{2}{*}{$\begin{array}{c}\text { Kesimpulan kemiripan Masjid } \\
\text { Raya Makassar berdasarkan } \\
\text { Ching (1996) dan Utami } \\
(2004)\end{array}$} \\
\hline & & & $\begin{array}{c}\text { Jendral } \\
\text { sudirman }\end{array}$ & $\begin{array}{c}\text { Pondok } \\
\text { Pesantren } \\
\text { Nahdatul } \\
\text { Qurra'a } \\
\text { Walhuffadz }\end{array}$ & $\begin{array}{l}\text { Shihatul } \\
\text { Iman }\end{array}$ & $\begin{array}{c}\text { Lantja } \\
\text { Abduh } \\
\text { Massi }\end{array}$ & \\
\hline
\end{tabular}

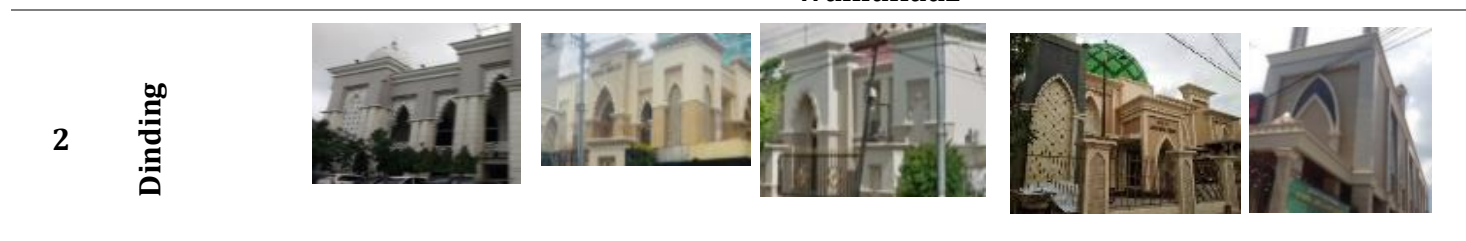

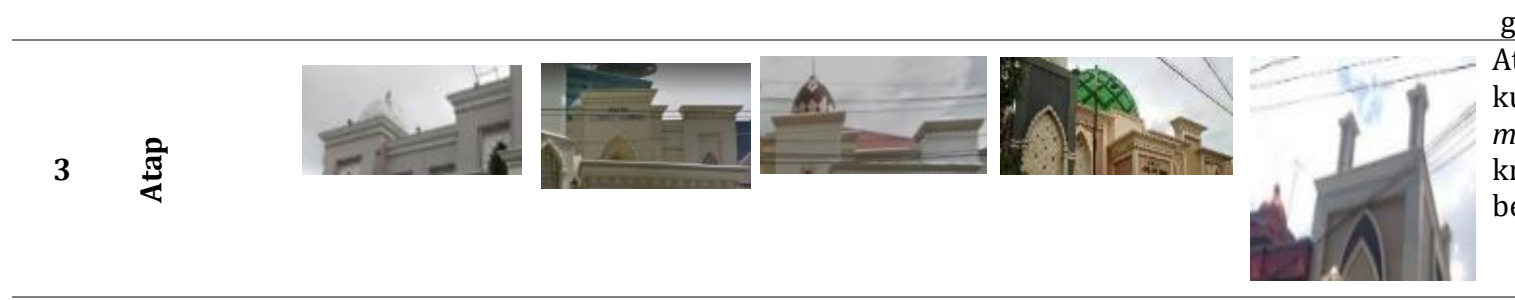

Tonjolan-tonjolan kolom pada dinding masjid, penggunaan warna monochrome (krem muda dan krem tua) dan ornamen yang berpola geometri.

Atap plat yang bertingkat

kubah, penggunaan warna monochrome (krem muda dan krem tua) dan ornamen yang berpola geometri.

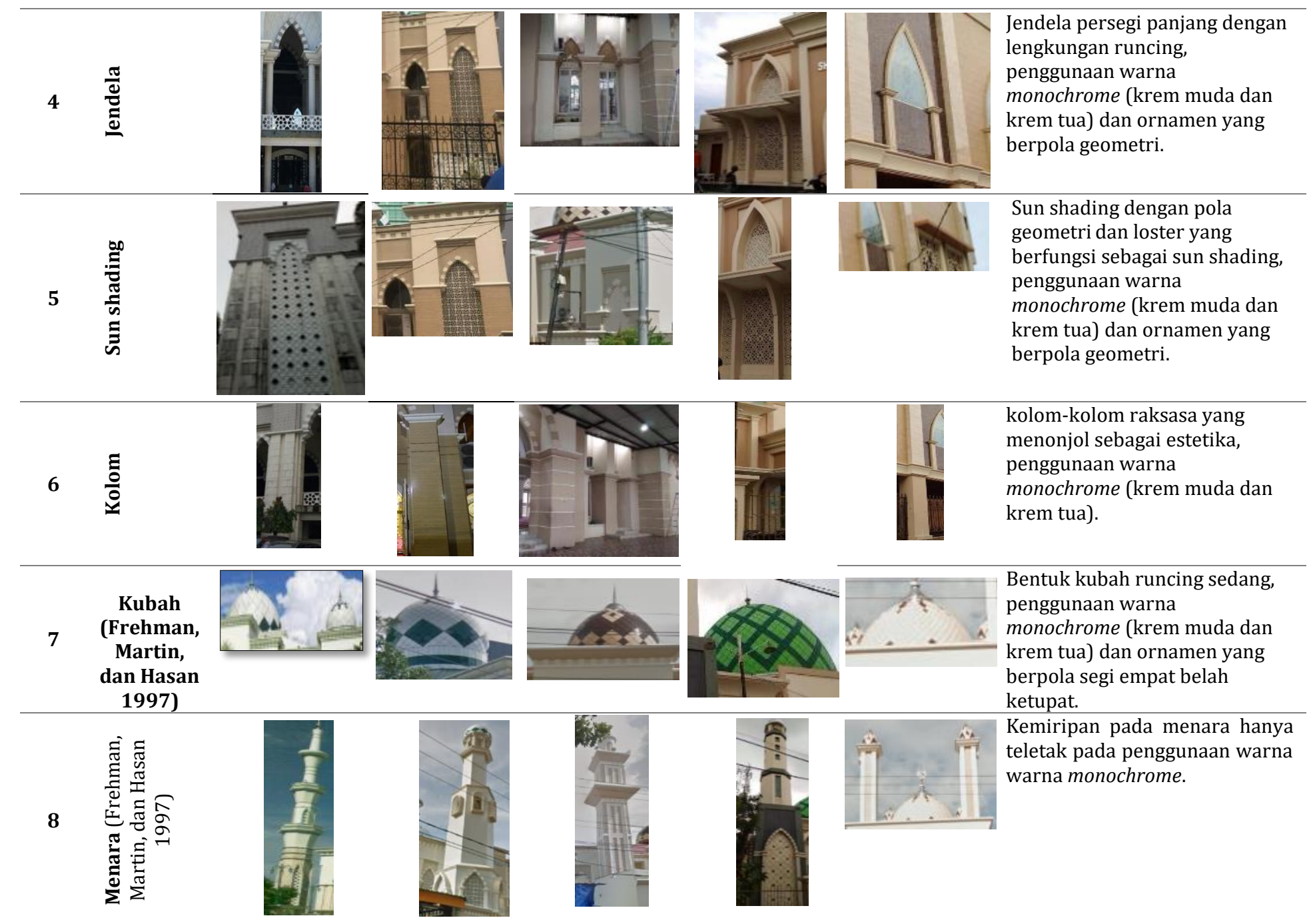




\section{KESIMPULAN}

Penelitian ini menyimpulkan bahwa terdapat pengaruh fasad Masjid Raya Makassar terhadap Masjid kecil lainnya, terlihat terletak pada bentuk lengkungan pada gerbang-gerbang Masjid, penggunaan kolom-kolom besar, atap plat, bentuk yang simetris dan mudah dibentuk sesuai dengan ukuran lahan, bentuk kubah yang berasal dari satu pabrik, ornamen dan irama. Faktor-faktor yang mempengaruhi yaitu, kemudahan dalam pembangunan, masukan dari beberapa jamaah dan pengurus Masjid. Elemen yang sangat mirip terutama pada bentuk pointed arch pada jendela dan gerbang pintu masuk. Namun, pointed arch pada jendela merupakan desain yang bertolak belakang dengan kaidah-kaidah Islami. Sebaiknya bentuk lengkungan dan ukurannya harus menyesuaikan dengan bentuk yang ada di Masjid Nabawi.

Hasil penelitian ini dapat digunakan sebagai bahan pertimbangan baik bagi para Arsitek dalam mendesain maupun bagi masyarakat atau lembaga pengurus masjid secara umum. Hasil penelitian ini berkaitan erat dengan desain perancangan dan menjadi tolak ukur untuk suatu bangunan yang disukai dan banyak diminati masyarakat saat ini dan nantinya. Lebih dari itu, penelitian ini juga merupakan referensi untuk mengkaji kemiripan arsitektur masjid ataupun bangunan lainnya dalam studi mahasiswa arsitektur agar dapat membawa kemajuan pada sistem pendidikan mahasiswa arsitektur.

Diperlukan untuk melihat aspek-aspek kemiripan elemen-elemen fasad sehingga, Arsitek dapat menciptakan desain terbaru yang lebih indah. Penelitian ini perlu dilanjutkan, untuk meneliti masjid-masjid kecil yang mirip dengan Masjid Raya yang berada diluar Kota Makassar.

\section{DAFTAR REFERENSI}

Ching, Francis D.K. 1996. Ilustrasi Desain Interior. Jakarta: Erlangga.

Fanani, A. 2009. Arsitektur Masjid. Yogyakarta: Bentang Pustaka.

Frehman, Martin, dan Hasan. 1997. "The Mosque: History Architectural Development."

Utami. 2004. Integrasi Konsep Islami Dan Konsep Arsitektur Modern Pada Perancangan Arsitektur.

Utami, dan Dkk. 2013. Kajian bentuk dan fasade hotel hilton bandung,. Institut Teknologi Nasional. Vol. 1. Bandung.

Utami,dkk. 2014. "Kajian Bentuk dan Fasad Hotel Gino Feruci Bandung." Institut Teknologi Nasional 1 (4). 